\title{
Diverse Nrf2 Activators Coordinated to Cobalt Carbonyls Induce Heme Oxygenase-1 and Release Carbon Monoxide in vitro and in vivo
}

Aniket Nikam, Anthony Ollivier, Michael Rivard, Jayne Louise Wilson, Kevin Mebarki, Thierry Martens, Jean-Luc Dubois-Randé, Roberto Motterlini and Roberta Foresti

\section{Table of Contents}

\section{MATERIALS AND METHODS.} 3

General procedure for propargylation of carboxylic acids. . .3

Synthesis of Prop-2-yn-1-yl 4-oxo-4H-chromene-2-carboxylate (8)... .3

Synthesis of Prop-2-yn-1-yl (2E)-3-(3,4-dimethoxyphenyl)prop-2-enoate (12)..................................3

Synthesis of 3,3'-methanediylbis[1-(prop-2-yn-1-yl)-1H-indole] (9) ....................................................

Spectroscopy

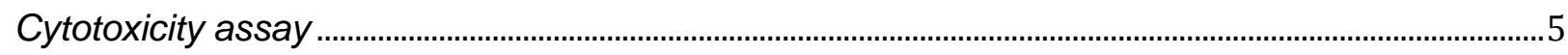

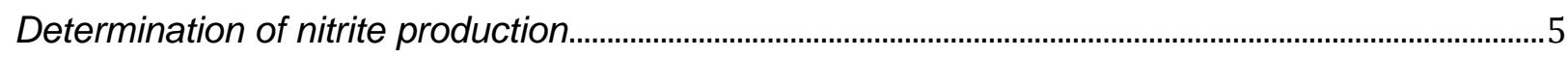

Detection of CO release from HYCOs using the COP-1 fluorescent probe ........................................6

Detection of CO release from HYCOs using a carbonmonoxy hemoglobin ( $\mathrm{HbCO}$ ) assay and

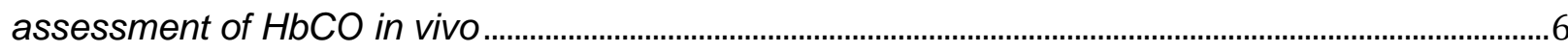

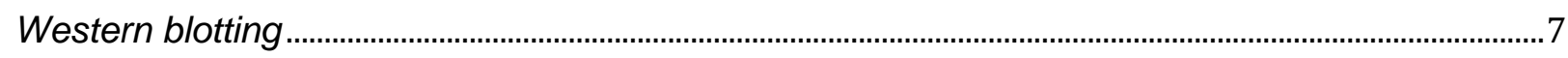

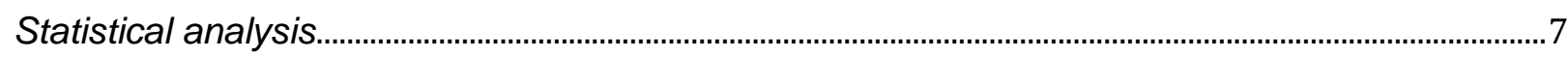

Figure S1. Absorption spectra showing the conversion of deoxy- $\mathrm{Hb}$ to $\mathrm{HbCO}$ over time after addition of compounds 3-7 in vitro.

Figure S2. Fluorescence spectra of a CO-sensitive probe (COP-1) after addition of compounds 3-7 in vitro.

Figure S3. Detection of intracellular CO measured with COP-1 after exposure of BV2 microglia cells to $10 \mu \mathrm{M}$ compounds 3-7..

Figure S4. Densitometric analysis for Nrf2 (2 h) and HO-1 (6h) protein expression in BV2 cells pre-treated with $1 \mathrm{mM} \mathrm{N}$-acetylcysteine (NAC) for $18 \mathrm{~h}$ and then incubated with $10 \mu \mathrm{M}$ compound $\mathbf{3}$ or compound 7 .

Figure S5. ${ }^{1} \mathrm{H} \mathrm{NMR}\left(400 \mathrm{MHz}, \mathrm{CDCl}_{3}\right)$ and ${ }^{13} \mathrm{C} \mathrm{NMR}\left(100 \mathrm{MHz}, \mathrm{CDCl}_{3}\right)$ spectra of compound 8.

Figure S6. ${ }^{1} \mathrm{H}$ NMR $\left(400 \mathrm{MHz}, \mathrm{C}_{6} \mathrm{D}_{6}\right)$ and ${ }^{13} \mathrm{C} \mathrm{NMR}\left(100 \mathrm{MHz}, \mathrm{C}_{6} \mathrm{D}_{6}\right)$ spectra of compound 3.13

Figure S7. ${ }^{1} \mathrm{H} \mathrm{NMR}\left(400 \mathrm{MHz}, \mathrm{CDCl}_{3}\right)$ and ${ }^{13} \mathrm{C} \mathrm{NMR}\left(100 \mathrm{MHz}, \mathrm{CDCl}_{3}\right)$ spectra of compound 9.

Figure S8. ${ }^{1} \mathrm{H}$ NMR $\left(400 \mathrm{MHz}, \mathrm{C}_{6} \mathrm{D}_{6}\right)$ and ${ }^{13} \mathrm{C} \mathrm{NMR}\left(100 \mathrm{MHz}, \mathrm{C}_{6} \mathrm{D}_{6}\right)$ spectra of compound 4.15

Figure S9. ${ }^{1} \mathrm{H}$ NMR $\left(400 \mathrm{MHz}, \mathrm{C}_{6} \mathrm{D}_{6}\right)$ and ${ }^{13} \mathrm{C} \mathrm{NMR}\left(100 \mathrm{MHz}, \mathrm{C}_{6} \mathrm{D}_{6}\right)$ spectra of compound $\mathbf{5 . 1 6}$ 
Figure S10. ${ }^{1} \mathrm{H}$ NMR $\left(400 \mathrm{MHz}, \mathrm{C}_{6} \mathrm{D}_{6}\right)$ and ${ }^{13} \mathrm{C} \mathrm{NMR}\left(100 \mathrm{MHz}, \mathrm{C}_{6} \mathrm{D}_{6}\right)$ spectra of compound 6.

Figure S11. ${ }^{1} \mathrm{H}$ NMR $\left(400 \mathrm{MHz}, \mathrm{C}_{6} \mathrm{D}_{6}\right)$ and ${ }^{13} \mathrm{C} \mathrm{NMR}\left(100 \mathrm{MHz}, \mathrm{C}_{6} \mathrm{D}_{6}\right)$ spectra of compound 12.

Figure S12. ${ }^{1} \mathrm{H}$ NMR $\left(400 \mathrm{MHz}, \mathrm{C}_{6} \mathrm{D}_{6}\right)$ and ${ }^{13} \mathrm{C} \mathrm{NMR}\left(100 \mathrm{MHz}, \mathrm{C}_{6} \mathrm{D}_{6}\right)$ spectra of compound 7 . 


\section{MATERIALS AND METHODS}

\section{General procedure for propargylation of carboxylic acids}

To a solution of carboxylic acid (1.0 equiv) in $\mathrm{CH}_{3} \mathrm{CN}(0.1 \mathrm{M})$ were added $\mathrm{K}_{2} \mathrm{CO}_{3}(1.1$ equiv) and propargyl bromide solution (80 wt. \% in toluene) (1.1 equiv). After $17 \mathrm{~h}$ of stirring at $70^{\circ} \mathrm{C}$, the reaction mixture was filtered and concentrated in vacuo. The crude was dissolved in a mixture $\mathrm{Et}_{2} \mathrm{O} / \mathrm{NaHCO}_{3}$ saturated solution (1/1) and the aqueous layer was extracted by $\mathrm{Et}_{2} \mathrm{O}$. The resulting organic layers were washed with brine, dried on $\mathrm{MgSO}_{4}$, filtered and concentrated in vacuo.

\section{Synthesis of Prop-2-yn-1-yl 4-oxo-4H-chromene-2-carboxylate (8)}

Following the general procedure for propargylation of carboxylic acids, chromone-2carboxylic acid $(380 \mathrm{mg}, 2.00 \mathrm{mmol}$ ) was converted to crude oil. This resulting crude product was purified by flash silica gel column chromatography eluting with cyclohexane/EtOAc $(75 / 25)$ to give $8(157 \mathrm{mg}, 0.69 \mathrm{mmol})$ as a white solid in $35 \%$ yield. ${ }^{1} \mathrm{H}$ NMR $\left(400 \mathrm{MHz}, \mathrm{CDCl}_{3}\right) \delta 8.20$ (dd, $J=8.0,1.5 \mathrm{~Hz}, 1 \mathrm{H}$ ), 7.75 (ddd, $J=8.7$, 7.2, $1.7 \mathrm{~Hz}, 1 \mathrm{H}), 7.62(\mathrm{~d}, J=8.5 \mathrm{~Hz}, 1 \mathrm{H}), 7.46(\mathrm{~m}, 1 \mathrm{H}), 7.17(\mathrm{~s}, 1 \mathrm{H}), 4.99(\mathrm{~d}, J=2.5$ $\mathrm{Hz}, 2 \mathrm{H}), 2.60(\mathrm{t}, J=2.5 \mathrm{~Hz}, 1 \mathrm{H}) .{ }^{13} \mathrm{C}$ NMR $\left(100 \mathrm{MHz}, \mathrm{CDCl}_{3}\right) \delta 178.18,159.90,155.94$, 151.37, 134.86, 126.03, 125.78, 124.44, 118.78, 115.41, 76.40, 76.13, 54.05. Anal. Calcd for $\mathrm{C}_{13} \mathrm{H}_{8} \mathrm{O}_{4}(228,20): \mathrm{C}, 68.42 ; \mathrm{H}, 3.53 ; \mathrm{O}, 28.04$. Found: C, 68.36; $\mathrm{H}, 3.71 ; \mathrm{O}$, 27.87.

\section{Synthesis of Prop-2-yn-1-yl (2E)-3-(3,4-dimethoxyphenyl)prop-2-enoate (12)}

Following the general procedure for propargylation of carboxylic acids, 3,4dimethoxycinnamic acid (208 mg, $1.00 \mathrm{mmol}$ ) was converted to crude oil. This resulting crude product was purified by flash silica gel column chromatography eluting with cyclohexane/EtOAc (80/20) to give $12(214 \mathrm{mg}, 0.87 \mathrm{mmol})$ as a white solid in $87 \%$ yield. ${ }^{1} \mathrm{H}$ NMR $\left(400 \mathrm{MHz}, \mathrm{C}_{6} \mathrm{D}_{6}\right) \delta 7.85(\mathrm{~d}, J=15.9 \mathrm{~Hz}, 1 \mathrm{H}), 6.73(\mathrm{dd}, J=8.2,2.0 \mathrm{~Hz}$, $1 \mathrm{H}), 6.66(\mathrm{~d}, J=1.9 \mathrm{~Hz}, 1 \mathrm{H}), 6.36(\mathrm{~d}, J=15.9 \mathrm{~Hz}, 1 \mathrm{H}), 6.32(\mathrm{~d}, J=8.3 \mathrm{~Hz}, 1 \mathrm{H}), 4.62$ (d, $J=2.4 \mathrm{~Hz}, 2 \mathrm{H}$ ), 3.26 (s, 3H), $3.26(\mathrm{~s}, 3 \mathrm{H}), 2.00(\mathrm{t}, J=2.4 \mathrm{~Hz}, 1 \mathrm{H}) \cdot{ }^{13} \mathrm{C}$ NMR (100 $\left.\mathrm{MHz}, \mathrm{C}_{6} \mathrm{D}_{6}\right) \delta 165.95,152.20,150.12,146.03,127.38,122.74,114.97,111.53,110.47$, 78.50, 74.81, 55.25, 55.25, 51.68. Anal. Calcd for $\mathrm{C}_{14} \mathrm{H}_{14} \mathrm{O}_{4}$ (246.26): C, 68.28; $\mathrm{H}$, 5.73; O, 25.99. Found: C, 67.94; H, 5.77; O, 25.78. 


\section{Synthesis of 3,3'-methanediylbis[1-(prop-2-yn-1-yl)-1H-indole] (9)}

To a suspension of sodium hydride (60\% dispersion in mineral oil) (176 mg, 4.40 mmol, 2.2 equiv.) in anhydrous THF ( $30 \mathrm{~mL}$ ) was added under argon diindolylmethane (492 mg, $2.00 \mathrm{mmol}, 1.0$ equiv.) After $5 \mathrm{~min}$ of stirring at $20^{\circ} \mathrm{C}$, propargyl bromide solution (80 wt. \% in toluene) (1.11 mL, $10.00 \mathrm{mmol}, 5.0$ equiv.) was introduced dropwise. After $40 \mathrm{~h}$ of stirring at $70^{\circ} \mathrm{C}$, the reaction mixture was concentrated in vacuo and dissolved in a mixture $\mathrm{Et}_{2} \mathrm{O} / \mathrm{H}_{2} \mathrm{O}(1 / 1)$. After phase separation, the aqueous layer was extracted twice by diethyl ether. The organic layer was then washed by a saturated solution of $\mathrm{NaCl}$, dried over $\mathrm{MgSO}_{4}$, filtered and concentrated in vacuo. The resulting crude product was purified by flash silica gel column chromatography eluting with cyclohexane/EtOAc (95/5 $\rightarrow$ 90/10) to give 9 (259 $\mathrm{mg}, 0.80 \mathrm{mmol}$ ) as an orange-brown solid in $40 \%$ yield. ${ }^{1} \mathrm{H}$ NMR $\left(400 \mathrm{MHz}, \mathrm{CDCl}_{3}\right) \delta 7.63(\mathrm{~d}, J=7.9 \mathrm{~Hz}, 2 \mathrm{H}), 7.40(\mathrm{~d}, J=$ $8.2 \mathrm{~Hz}, 2 \mathrm{H}), 7.26(\mathrm{~m}, 2 \mathrm{H}), 7.12(\mathrm{~m}, 2 \mathrm{H}), 6.94(\mathrm{~s}, 2 \mathrm{H}), 4.80(\mathrm{~d}, J=2.5 \mathrm{~Hz}, 4 \mathrm{H}), 4.23(\mathrm{~s}$, $2 \mathrm{H}), 2.35(\mathrm{t}, J=2.5 \mathrm{~Hz}, 2 \mathrm{H}) .{ }^{13} \mathrm{C} \mathrm{NMR}\left(100 \mathrm{MHz}, \mathrm{CDCl}_{3}\right) \delta 136.29,128.43,125.48$, $121.85,119.54,119.27,115.15,109.29,78.04,73.16,35.62,21.00$. Anal. Calcd for $\mathrm{C}_{23} \mathrm{H}_{18} \mathrm{~N}_{2}+1 / 3 \mathrm{H}_{2} \mathrm{O}$ (328.41): C, 84.12; $\mathrm{H}, 5.73 ; \mathrm{N}, 8.53$. Found: C, 84.19; H, 5.72; N, 8.23 .

\section{Spectroscopy}

Fluorescence spectra were obtained using a JASCO FP-6300 scanning spectrofluorometer equipped with a DC powered 150W Xenon lamp contained within a sealed housing, excitation and emission holographic monochromators optimized for the UV, silicon photodiode and photomultiplier detection systems for the excitation and emission monochromators, respectively. Absorption spectra were recorded using a JASCO V-530 UV/Vis scanning spectrophotometer equipped with a double beam, single monochromator. Samples for emission and absorption measurements were contained in $1 \mathrm{~cm} \times 1 \mathrm{~cm} 4.5 \mathrm{ml}$ polystyrene cuvettes. Data were recorded and analysed using JASCO Spectra Manager Software. Spectrophotometric assays were used to measure nitrite production, a marker for inflammation, as well as cytotoxicity by measuring lactate dehydrogenase release from BV2 microglia cells treated with HYCOs (specific method descriptions provided below). In each case, raw absorbance values were obtained using an Appliskan filter-based multimode microplate reader (Thermo Scientific) equipped with Skanit ${ }^{\circledR}$ Software for data analysis. When applicable, 
data processing was performed in Excel and all data were plotted using GraphPad Prism software version 5.0 (San Diego, CA).

\section{Cytotoxicity assay}

Cytotoxicity was evaluated in BV2 microglia cells after incubation with increasing concentrations of HYCOs using a Cytotoxicity Detection Kit (LDH) (Roche Applied Science) to measure lactate dehydrogenase released from damaged cells ${ }^{1 ; 2}$. The assay was performed according to the manufacturer's instructions. Cells were seeded in 24-well plates and treated for $24 \mathrm{~h}$ with different concentrations of $\operatorname{HYCOs}(1,2.5,5$, 10 and $20 \mu \mathrm{M}$ ). X-100 Triton solution ( $2 \%$ ) prepared in medium was used as a positive control (100\% cytotoxicity).

\section{Determination of nitrite production}

BV2 microglia cells were treated with $0.5 \mu \mathrm{g} / \mathrm{ml}$ lipopolysaccharide (LPS) in the presence or absence of increasing concentrations of HYCOs. At the end of the incubation, nitrite levels were measured using the Griess method as previously described ${ }^{3}$.

\section{Determination of intracellular glutathione}

The 5,5' dithiobis-(2-nitrobenzoic acid) (DTNB) colorimetric assay was used for the measurement of reduced glutathione (GSH) as previously described by our group ${ }^{4}$. Briefly, BV2 microglia cells were seeded in 6-well-plates and incubated with $10 \mu \mathrm{M}$ HYCOs and dimethyl fumarate (DMF, positive control) for 3, 6 and $24 \mathrm{~h}$. At the end of the incubation period, cells were initially washed with phosphate buffers solution, then scraped in $600 \mu \mathrm{L}$ of $2 \%$ (w/v) 5-sulposalicylic acid solution and transferred to a $1.5 \mathrm{ml}$ microtube, and finally centrifuged for $5 \mathrm{~min}$ at $10,000 \times \mathrm{g}$. An aliquot of the supernatant $(500 \mu \mathrm{l})$ was then reacted with $0.5 \mathrm{ml}$ DTNB solution $(0.3 \mathrm{M}$ sodium phosphate buffer, $10 \mathrm{mM}$ EDTA and $0.2 \mathrm{mM}$ DTNB) and after $5 \mathrm{~min}$ the absorbance was read spectrophotometrically at $412 \mathrm{~nm}$ (extinction coefficient $14.3 \mathrm{mM}^{-1} \mathrm{~cm}^{-1}$ ).

\section{Detection of reactive oxygen species (ROS)}

ROS production in cells was measured using the fluorescent dye 2',7'dichlorofluorescin diacetate (Sigma Aldrich). Briefly, BV2 microglia were treated with control medium, $10 \mu \mathrm{M}$ compound 3 or compound 7 for $30 \mathrm{~min}$ at $37{ }^{\circ} \mathrm{C}$ prior to 
incubation with $40 \mu \mathrm{M} \mathrm{2',7'-dichlorofluorescin} \mathrm{diacetate} \mathrm{for} \mathrm{an} \mathrm{additional} 30 \mathrm{~min}$. Parallel experiments were conducted by pre-treating cells with $1 \mathrm{mM} \mathrm{N}$-acetylcysteine (NAC) for $18 \mathrm{~h}$ before incubation with HYCOs. ROS production was measured by flow cytometry using a CyAn ${ }^{\mathrm{TM}}$ ADP LX7 Analyzer (Beckman Coulter) (excitation = $495 \mathrm{~nm}$; emission $=529 \mathrm{~nm}$ ).

\section{Detection of $\mathrm{CO}$ release from $\mathrm{HYCO}$ using the COP-1 fluorescent probe}

The release of $\mathrm{CO}$ from HYCOs was assessed using COP-1, a fluorescent probe sensitive to $\mathrm{CO}^{5 ; 6}$. The fluorescence intensity of COP-1 $(2 \mu \mathrm{M}, \lambda \mathrm{ex}=475 \mathrm{~nm})$ in buffer was measured in a cuvette to obtain a background fluorescence spectrum and spectra were then recorded immediately after addition of $50 \mu \mathrm{M}$ HYCOs. The mean fluorescence intensity $(\mathrm{MFI})$ of 3 independent readings was calculated using the fluorescence intensity values recorded at $507 \mathrm{~nm}$ after $60 \mathrm{~min}$. To detect whether the HYCOs delivered $\mathrm{CO}$ to cells, BV2 microglia were initially suspended in Dulbecco Phosphate Buffer Solution (+Ca,+Mg; Gibco ${ }^{\circledR}$ Cell Culture, Life Technologies) and then treated with HYCOs at a concentration of $10 \mu \mathrm{M}$ for 15 min at $37{ }^{\circ} \mathrm{C}$ in $5 \mathrm{ml}$ polypropylene round-bottom tubes (BD Falcon, Dominique Dutscher). Cells were then incubated for 30 min with $1 \mu \mathrm{M}$ COP-1. Intracellular fluorescence of COP-1 was measured using a CyAn ${ }^{T M}$ ADP LX7 Analyzer (Beckman Coulter) as previously reported ${ }^{6}$.

\section{Detection of CO release from HYCOs using a carbonmonoxy hemoglobin $(\mathrm{HbCO})$ assay and assessment of $\mathrm{HbCO}$ in vivo}

The release of $\mathrm{CO}$ from HYCOs was assessed spectrophotometrically by measuring the conversion of deoxyhemoglobin to carbonmonoxy hemoglobin $(\mathrm{HbCO})$ using a method previously described ${ }^{7}$. Briefly, fresh mouse blood $(0.5 \mathrm{ml})$ was initially collected in a tube containing $10 \mu$ EDTA (10\% solution) as anticoagulant. Using a Hamilton syringe, five microliters of blood were transferred to the bottom of a sealed cuvette containing a small magnetic bar and $4.5 \mathrm{ml}$ of tris(hydroxymethyl)aminomethane solution $(20 \mathrm{mM})$ previously deoxygenated with sodium dithionite. The solution in the cuvette was gently mixed on a magnetic stirrer and absorbance spectra between 400 and $500 \mathrm{~nm}$ were recorded over time using a JASCO spectrophotometer after addition of HYCOs (5.5 $\mu \mathrm{M}$ final concentration). The percent of $\mathrm{HbCO}$ was then calculated based on the absorbances at 420 and $432 \mathrm{~nm}$ 
with the reported extinction coefficients for mouse blood ${ }^{7}$. The same method was used to assess the level of $\mathrm{HbCO}$ in blood collected from mice $6 \mathrm{~h}$ after treatment with compound $\mathbf{3}$ or compound $\mathbf{7}$ ( $3 \mathrm{mg}$ ) by oral gavage.

\section{Western blotting}

Whole cell lysates (20 $\mu \mathrm{g}$ protein/sample), nuclear extracts (50 $\mu \mathrm{g}$ protein/sample) and tissue lysates (100 $\mathrm{\mu g}$ protein/sample) were resolved on 12 or $10 \%$ acrylamide gels. Proteins were transferred to polyvinylidene difluroride membranes (Millipore, Brussels, Belgium). Membranes were blocked for $1 \mathrm{~h}$ at room temperature in $1 \mathrm{x}$ Tris-buffered saline $(\mathrm{pH} 7.5)$ containing $0.1 \% \mathrm{v} / \mathrm{v}$ TWEEN 20 and $5 \% \mathrm{w} / \mathrm{v}$ non-fat dry milk and incubated overnight at $4{ }^{\circ} \mathrm{C}$ with the following primary antibodies: HO-1 (rabbit polyclonal, Enzo Life Sciences) and $\beta$-actin HRP linked antibody ( $\mathrm{C} 4$, mouse monoclonal, Santa Cruz Biotechnology) as a loading control or Nrf2 (clone C-20 rabbit polyclonal, Santa Cruz Biotechnology) and Lamin A/C (clone N-18, goat polyclonal, Santa Cruz Biotechnology) as a nuclear reference. Membranes were then incubated with secondary antibodies coupled to horseradish peroxidase (anti-rabbit or goat antimouse, donkey anti-goat or Cell Signaling Technology, Jackson ImmunoResearch) for $1 \mathrm{~h}$ at room temperature. Bands were detected with chemiluminescent substrates (Pierce $\mathrm{ECL}^{\circledR}$, Thermo Scientific or RevelBIOt ${ }^{\circledR}$ Intense, Ozyme) and images captured using a G:Box F3 Imagery Station and GeneSys Software (Syngene, Cambridge, UK).

\section{Statistical analysis}

Results are expressed as mean \pm S.E.M. and data analyses were performed using GraphPad Prism software version 5.0 (San Diego, CA). Differences were assessed by either a student t-test or One-way ANOVA combined with Bonferroni or Dunnet's multiple comparison tests. Statistically significant differences were accepted at a $\mathrm{P}$ value less than 0.05 . 
A

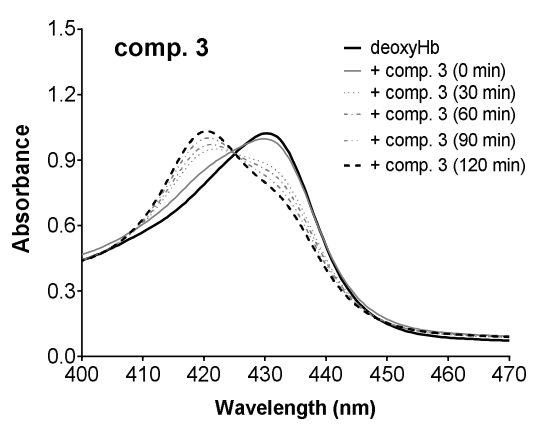

B

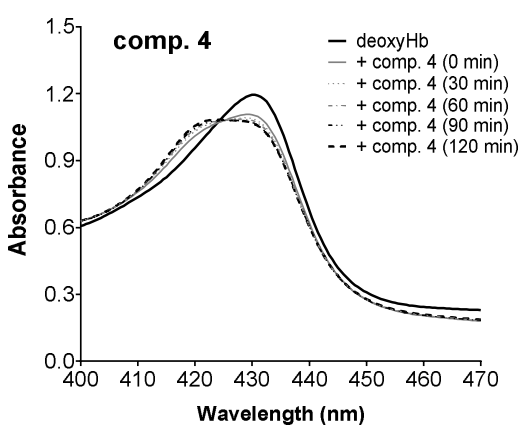

C

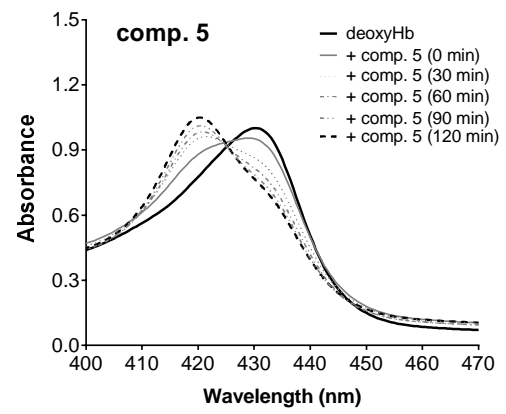

D

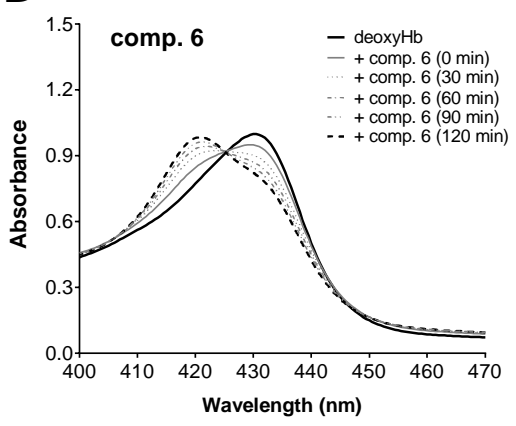

$\mathbf{E}$

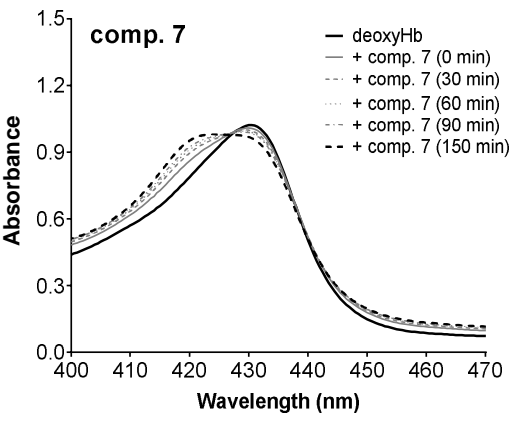

Figure S1. Absorption spectra showing the conversion of deoxy- $\mathrm{Hb}$ to $\mathrm{HbCO}$ over time after addition of compounds 3-7 in vitro. 
A

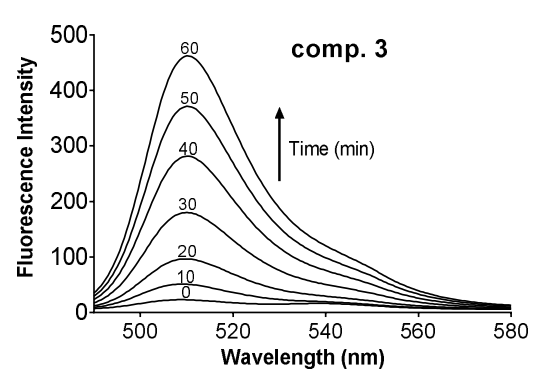

B

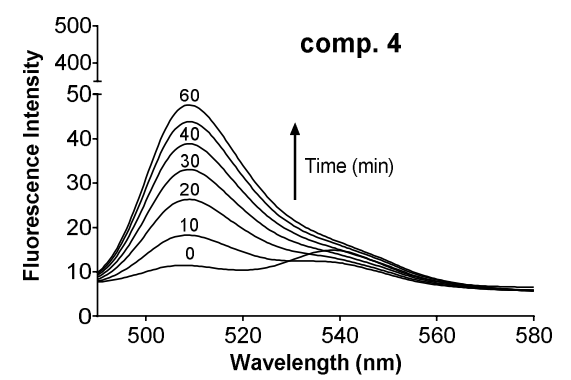

C

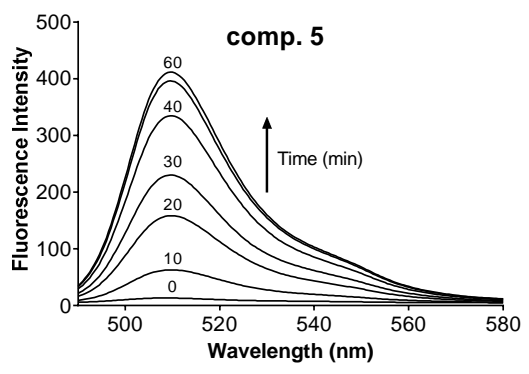

D

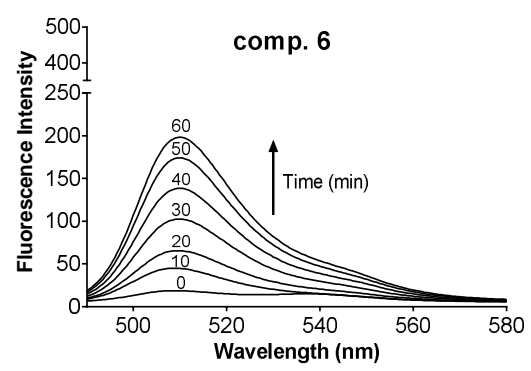

$\mathbf{E}$

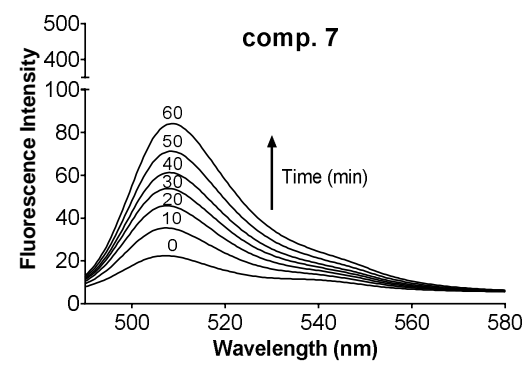

Figure S2. Fluorescence spectra of a CO-sensitive probe (COP-1) after addition of compounds 3-7 in vitro. 


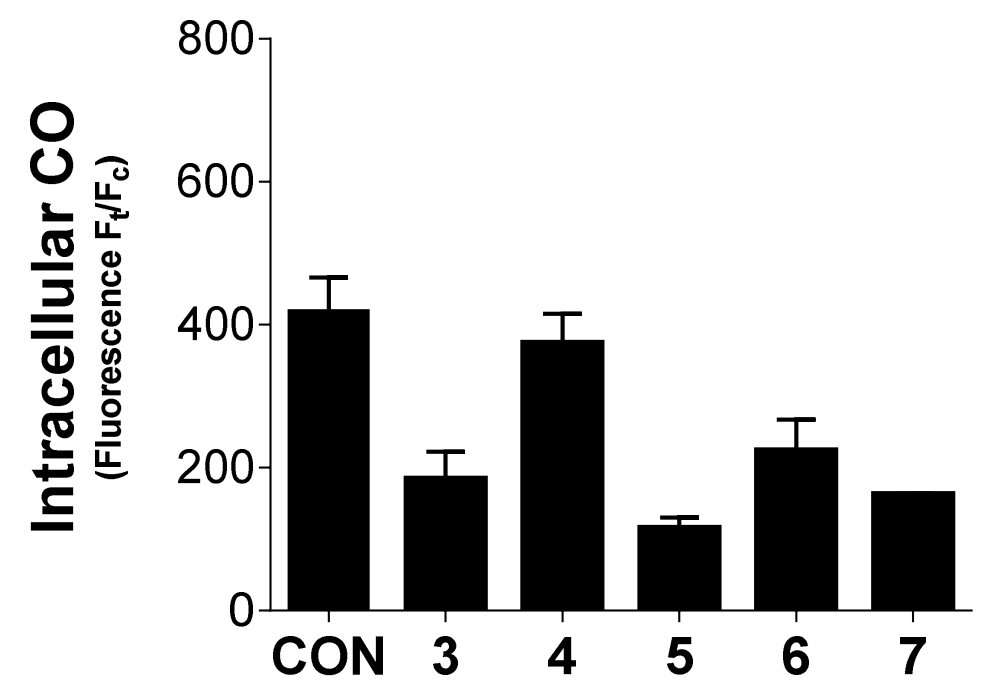

Figure S3. Detection of intracellular CO measured with COP-1 after exposure of BV2 microglia cells to $10 \mu \mathrm{M}$ compounds 3-7. 


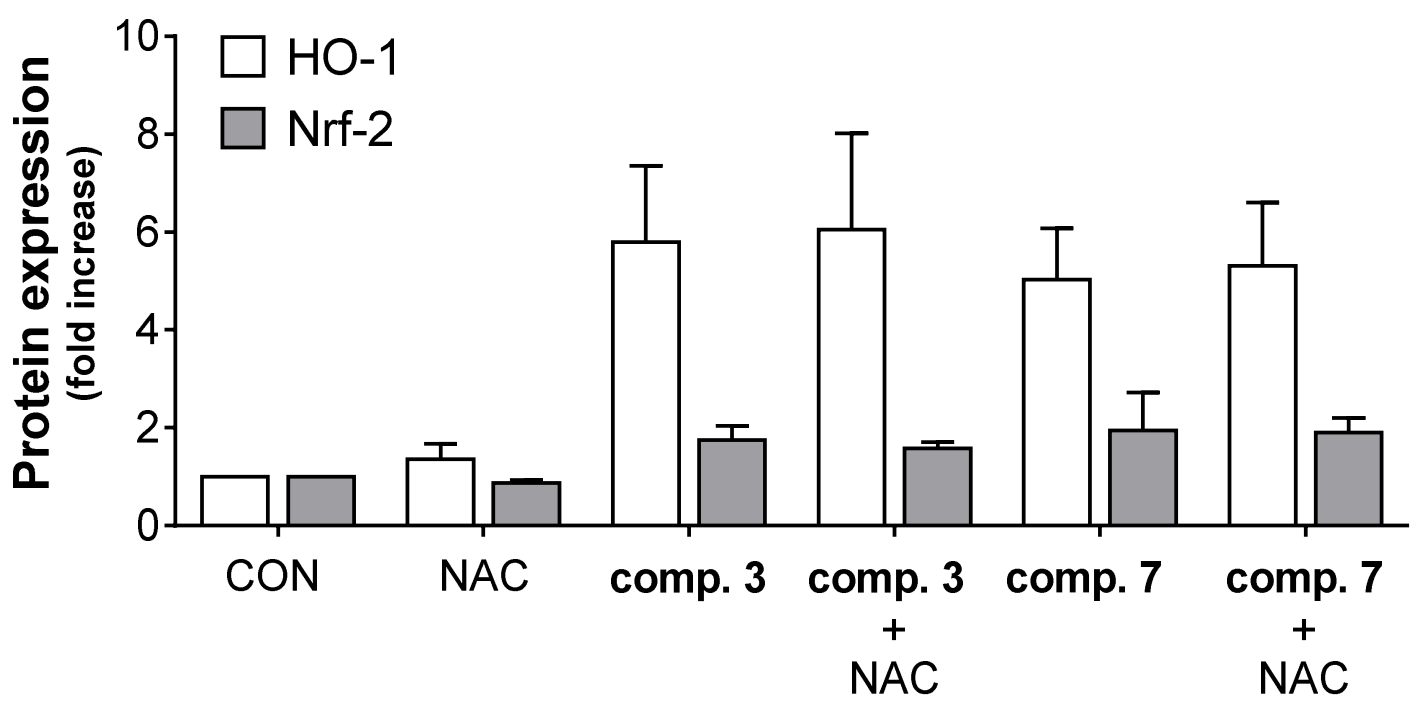

Figure S4. Densitometric analysis for Nrf2 (2 h) and HO-1 (6h) protein expression in BV2 cells pre-treated with $1 \mathrm{mM} \mathrm{N}$-acetylcysteine $(\mathrm{NAC})$ for $18 \mathrm{~h}$ and then incubated with $10 \mu \mathrm{M}$ compound $\mathbf{3}$ or compound $\mathbf{7}$. 


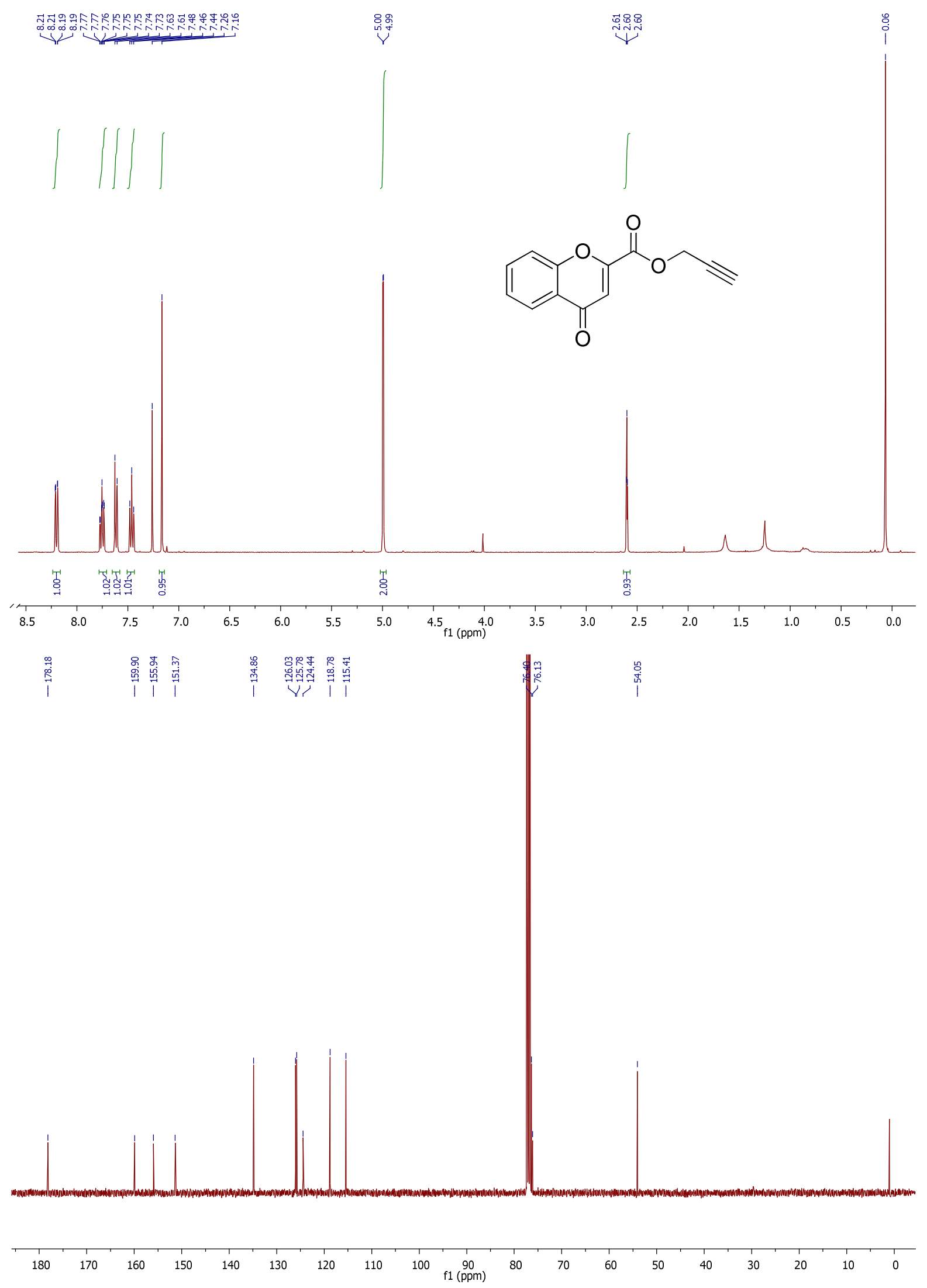

Figure S5. ${ }^{1} \mathrm{H}$ NMR $\left(400 \mathrm{MHz}, \mathrm{CDCl}_{3}\right)$ and ${ }^{13} \mathrm{C} \mathrm{NMR}\left(100 \mathrm{MHz}, \mathrm{CDCl}_{3}\right)$ spectra of compound 8. 

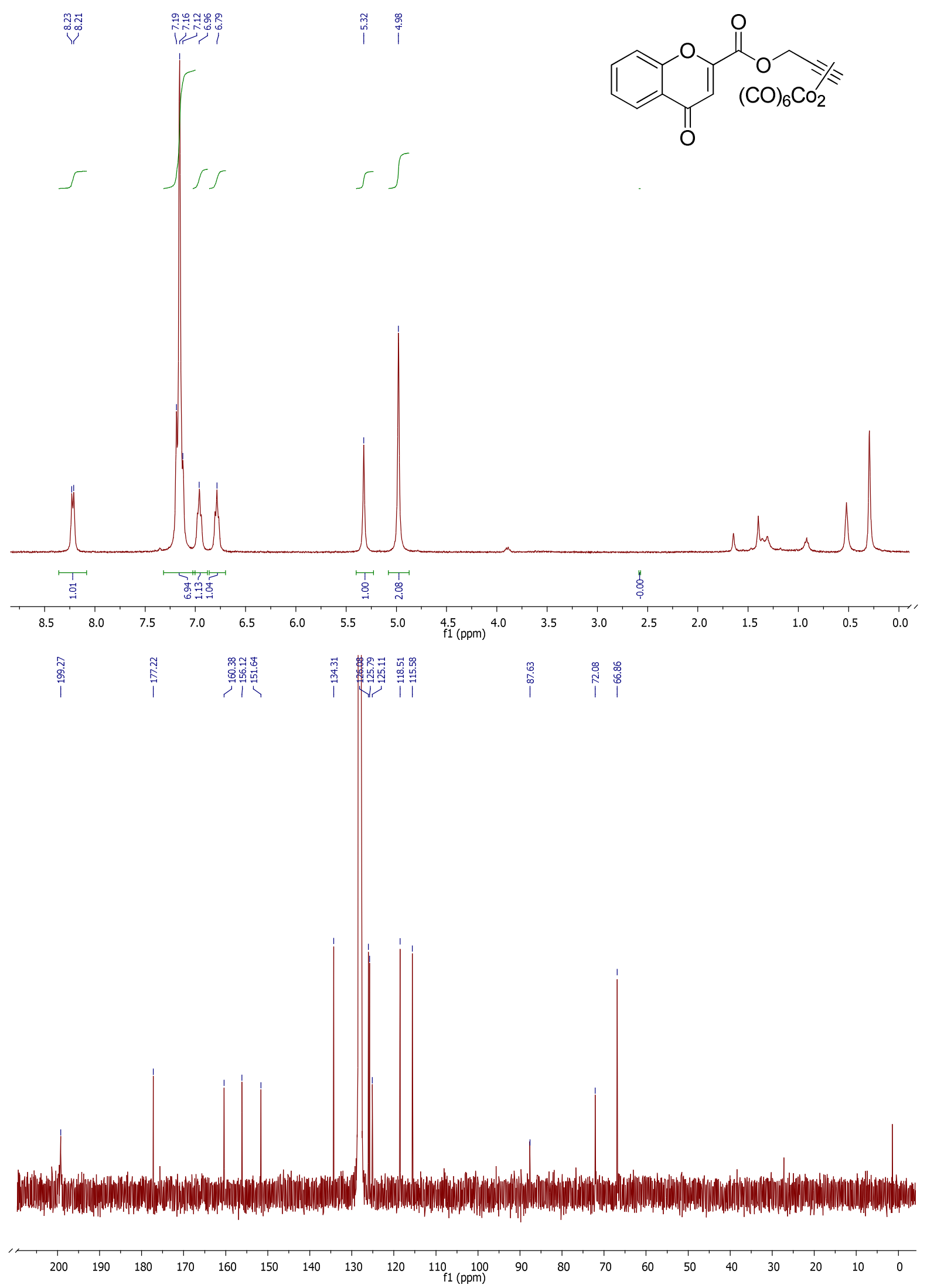

Figure S6. ${ }^{1} \mathrm{H}$ NMR $\left(400 \mathrm{MHz}, \mathrm{C}_{6} \mathrm{D}_{6}\right)$ and ${ }^{13} \mathrm{C} \mathrm{NMR}\left(100 \mathrm{MHz}, \mathrm{C}_{6} \mathrm{D}_{6}\right)$ spectra of compound 3. 

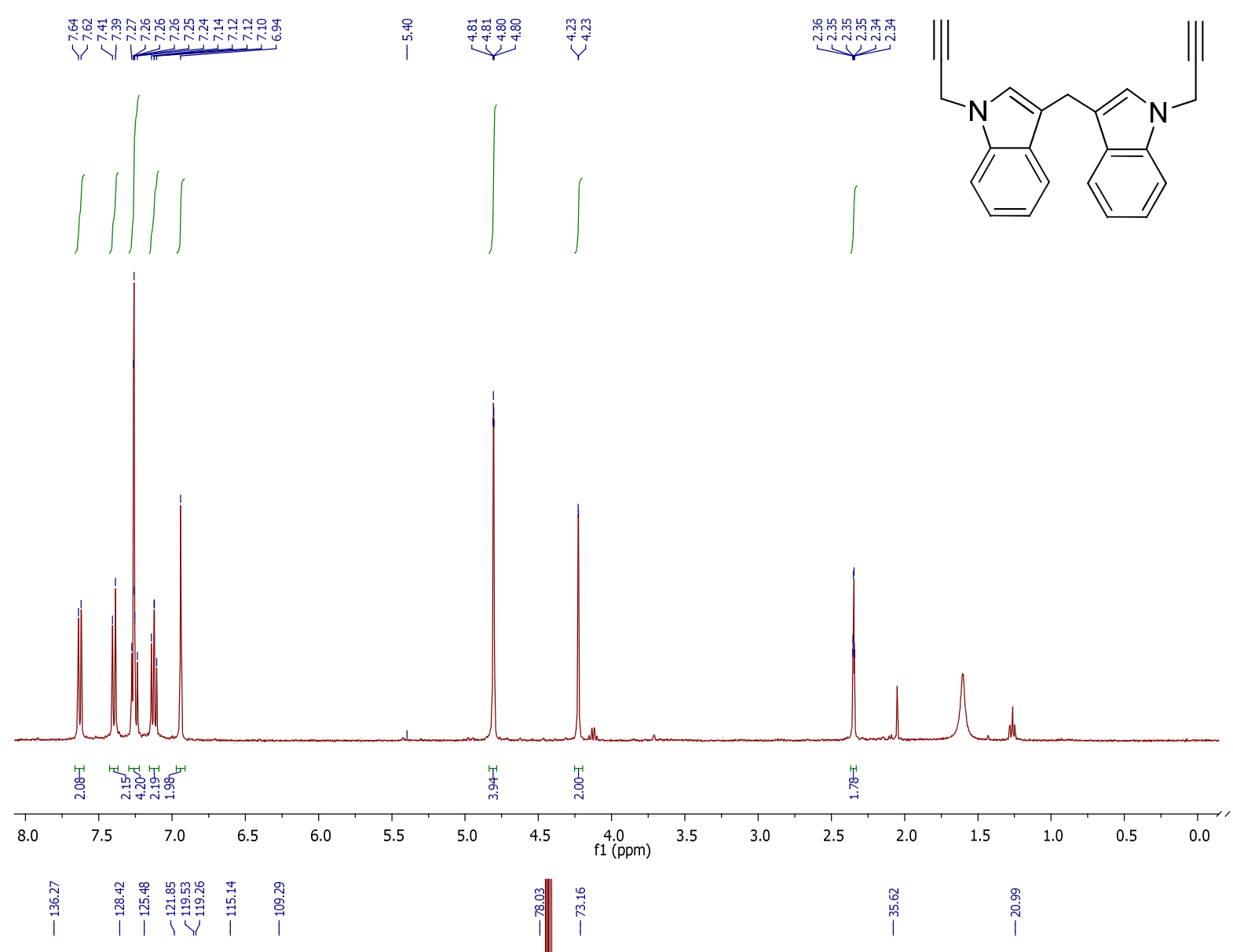

$\begin{array}{lllllllllllllllllllllllllllllll}135 & 130 & 125 & 120 & 115 & 110 & 105 & 100 & 95 & 90 & 85 & 80 & 75 & \begin{array}{c}70 \\ \mathrm{f} 1(\mathrm{ppm})\end{array} & 60 & 55 & 50 & 45 & 40 & 35 & 30 & 25 & 20 & 15 & 10 & 5 & 0\end{array}$

Figure S7. ${ }^{1} \mathrm{H} \mathrm{NMR}\left(400 \mathrm{MHz}, \mathrm{CDCl}_{3}\right)$ and ${ }^{13} \mathrm{C} \mathrm{NMR}\left(100 \mathrm{MHz}, \mathrm{CDCl}_{3}\right)$ spectra of compound 9. 

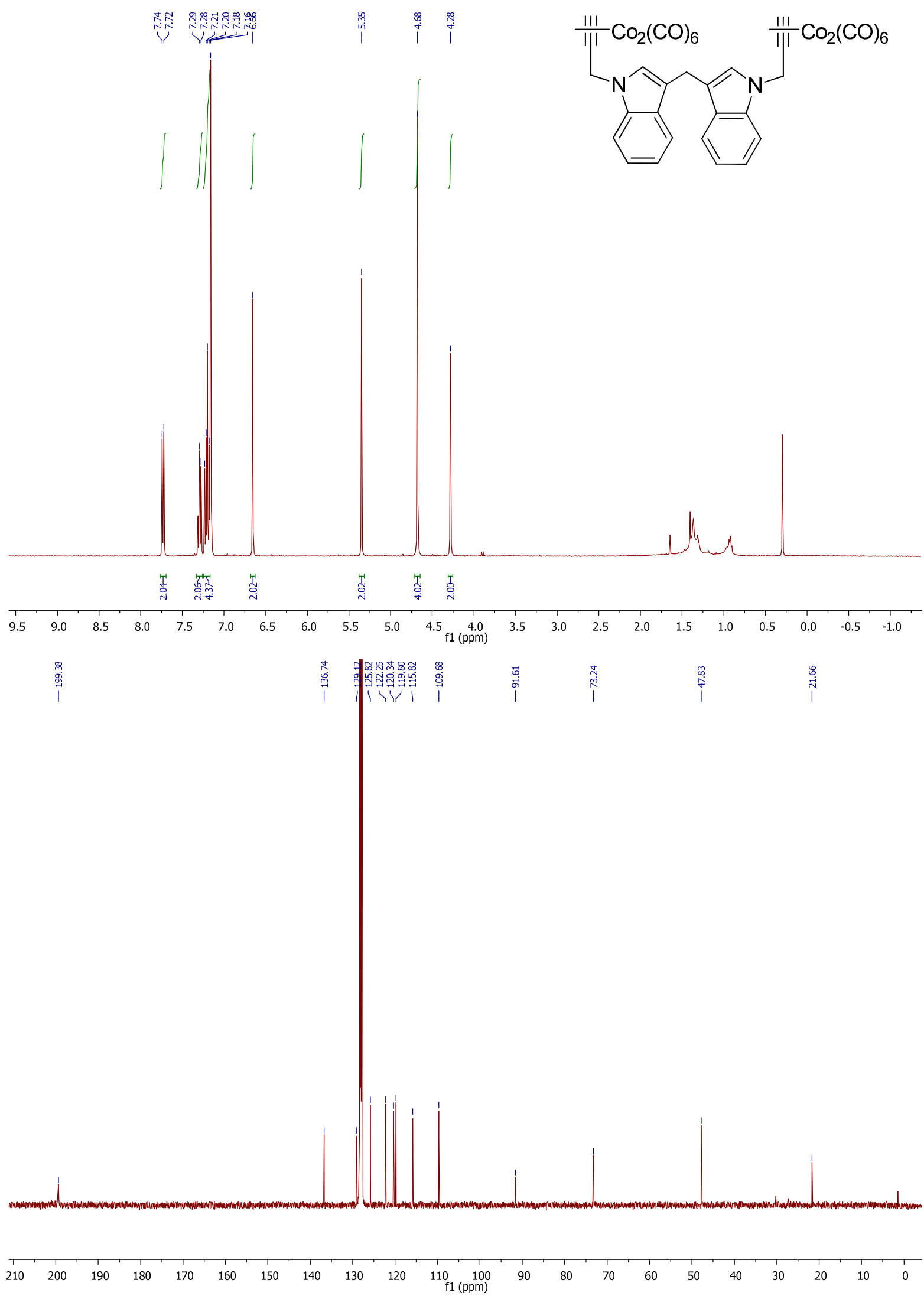

Figure S8. ${ }^{1} \mathrm{H}$ NMR $\left(400 \mathrm{MHz}, \mathrm{C}_{6} \mathrm{D}_{6}\right)$ and ${ }^{13} \mathrm{C} \mathrm{NMR}\left(100 \mathrm{MHz}, \mathrm{C}_{6} \mathrm{D}_{6}\right)$ spectra of compound 4. 

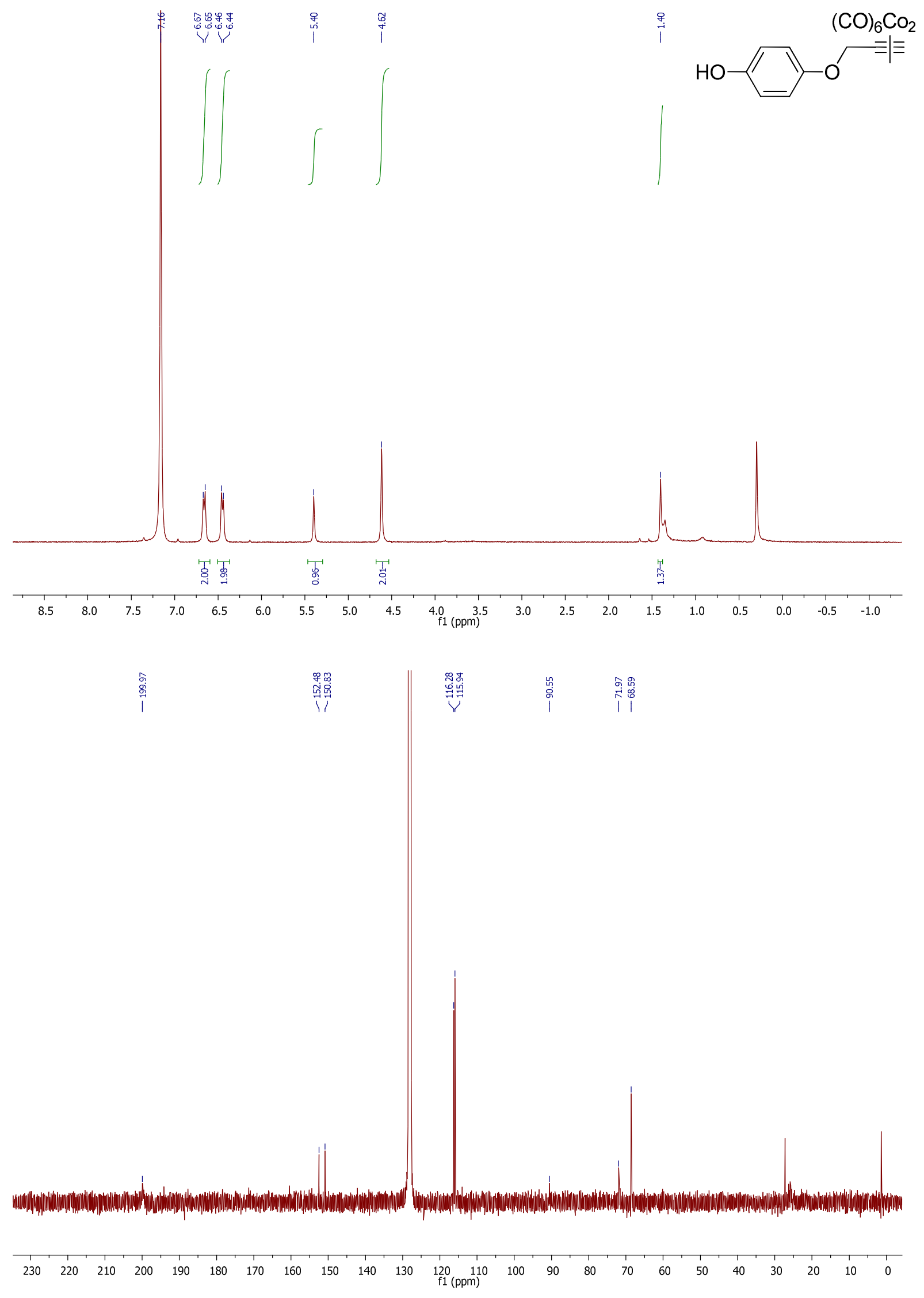

Figure S9. ${ }^{1} \mathrm{H}$ NMR $\left(400 \mathrm{MHz}, \mathrm{C}_{6} \mathrm{D}_{6}\right)$ and ${ }^{13} \mathrm{C} \mathrm{NMR}\left(100 \mathrm{MHz}, \mathrm{C}_{6} \mathrm{D}_{6}\right)$ spectra of compound 5. 

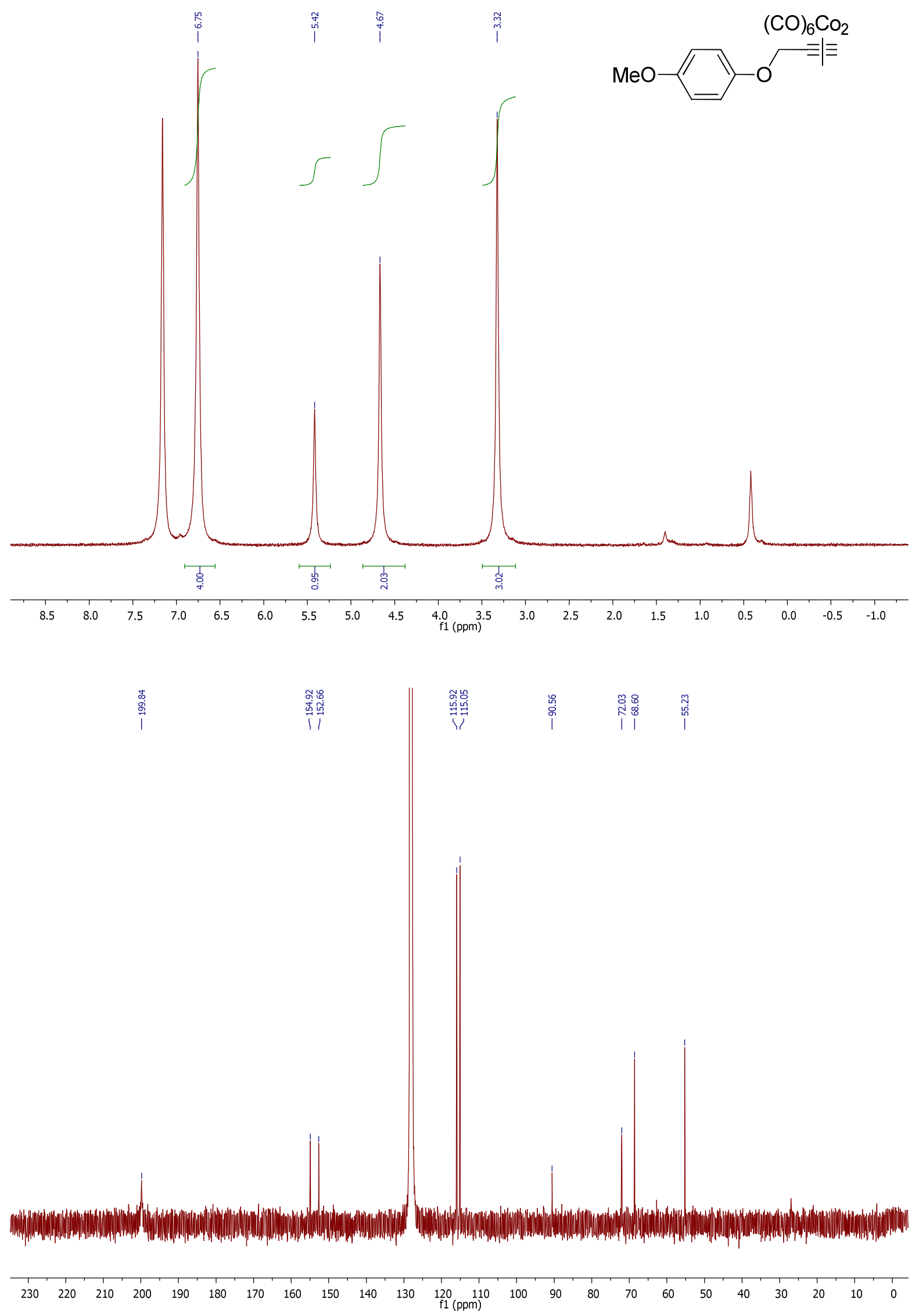

Figure S10. ${ }^{1} \mathrm{H}$ NMR $\left(400 \mathrm{MHz}, \mathrm{C}_{6} \mathrm{D}_{6}\right)$ and ${ }^{13} \mathrm{C} \mathrm{NMR}\left(100 \mathrm{MHz}, \mathrm{C}_{6} \mathrm{D}_{6}\right)$ spectra of compound 6. 

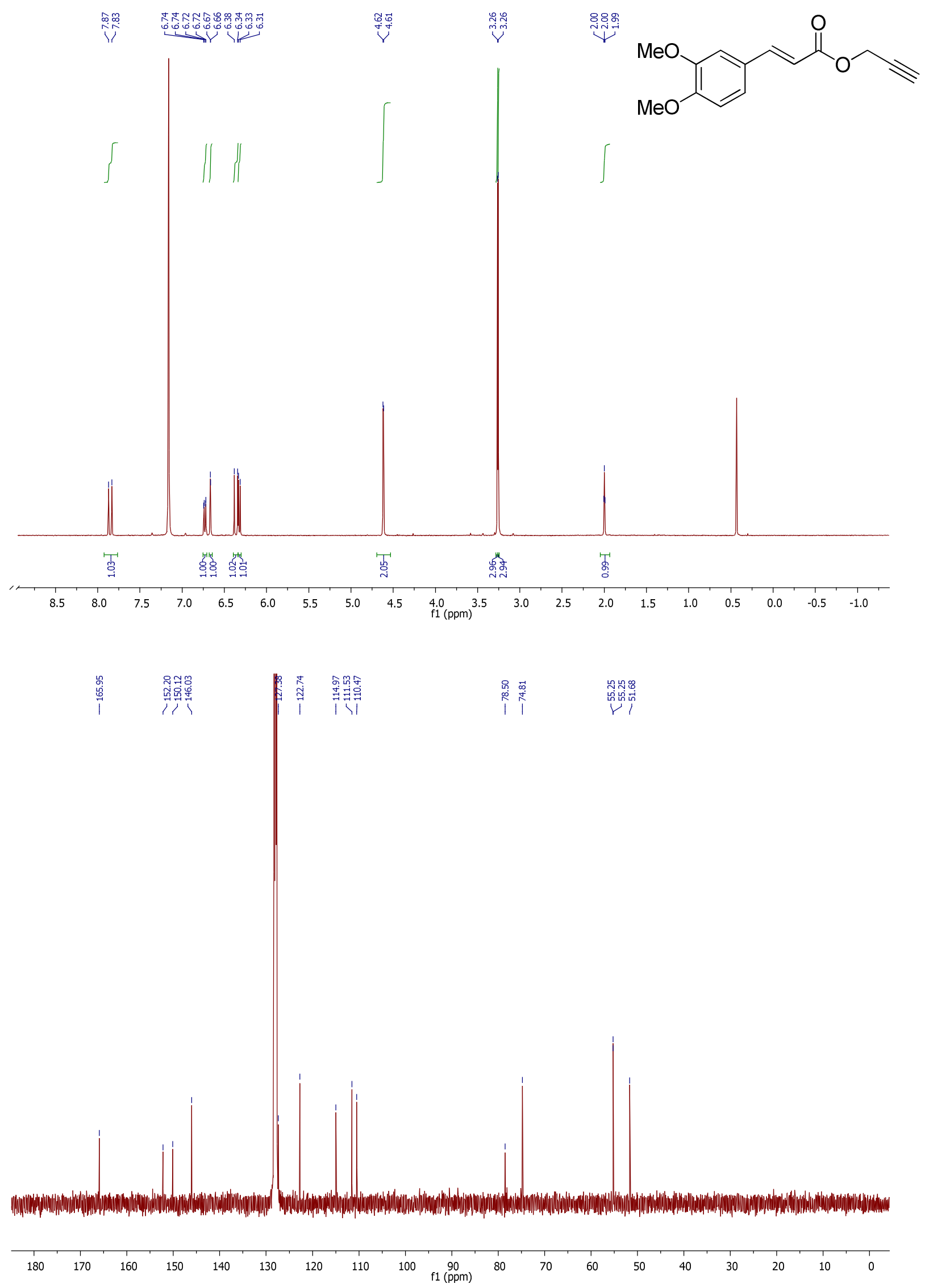

Figure S11. ${ }^{1} \mathrm{H}$ NMR $\left(400 \mathrm{MHz}, \mathrm{C}_{6} \mathrm{D}_{6}\right)$ and ${ }^{13} \mathrm{C}$ NMR $\left(100 \mathrm{MHz}, \mathrm{C}_{6} \mathrm{D}_{6}\right)$ spectra of compound 12. 

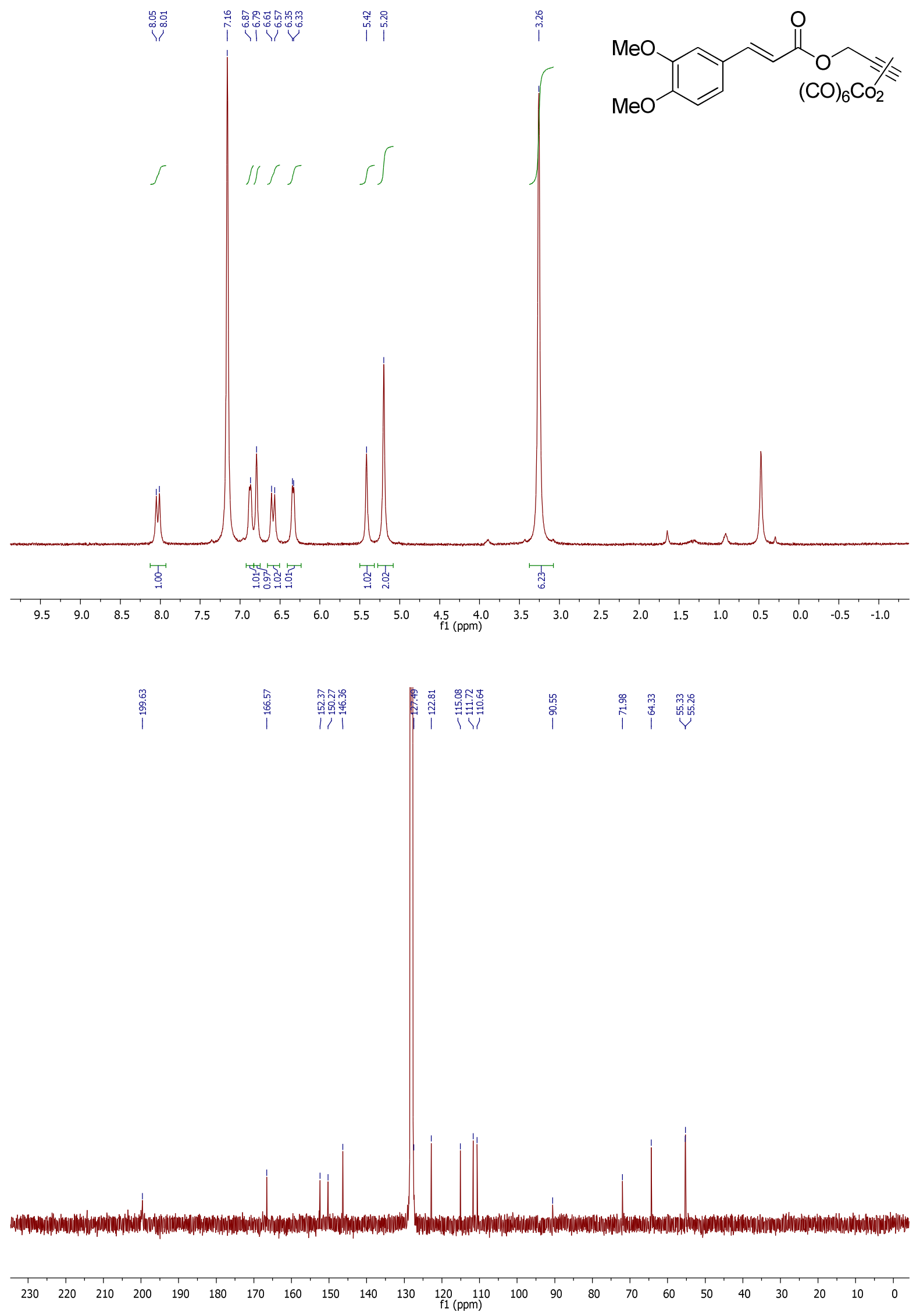

Figure S12. ${ }^{1} \mathrm{H}$ NMR $\left(400 \mathrm{MHz}, \mathrm{C}_{6} \mathrm{D}_{6}\right)$ and ${ }^{13} \mathrm{C}$ NMR $\left(100 \mathrm{MHz}, \mathrm{C}_{6} \mathrm{D}_{6}\right)$ spectra of compound 7. 


\section{REFERENCES}

(1) Sawle, P.; Hammad, J.; Fairlamb, I. J.; Moulton, B.; O'Brien, C. T.; Lynam, J. M.; Duhme-Klair, A. K.; Foresti, R.; and Motterlini, R. Bioactive properties of iron-containing carbon monoxide-releasing molecules (CO-RMs). J. Pharmacol. Exp. Ther. 2006, 318, 403-410.

(2) Fairlamb, I. J.; Lynam, J. M.; Moulton, B. E.; Taylor, I. E.; Duhme-Klair, A. K.;

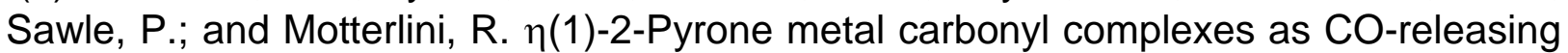
molecules (CO-RMs): a delicate balance between stability and $\mathrm{CO}$ liberation. Dalton Trans. 2007, 3603-3605.

(3) Atkin, A. J.; Williams, S.; Sawle, P.; Motterlini, R.; Lynam, J. M.; and Fairlamb, I. J. mu(2)-Alkyne dicobalt(0)hexacarbonyl complexes as carbon monoxide-releasing molecules (CO-RMs): probing the release mechanism. Dalton Trans. 2009, 19, 36533656.

(4) Sawle, P.; Foresti, R.; Mann, B. E.; Johnson, T. R.; Green, C. J.; and Motterlini, R. Carbon monoxide-releasing molecules (CO-RMs) attenuate the inflammatory response elicited by lipopolysaccharide in RAW264.7 murine macrophages. Br. J. Pharmacol. 2005, 145, 800-810.

(5) Michel, B. W.; Lippert, A. R.; and Chang, C. J. A Reaction-Based Fluorescent Probe for Selective Imaging of Carbon Monoxide in Living Cells Using a PalladiumMediated Carbonylation. J. Am. Chem. Soc. 2012, 134, 15668-15671.

(6) Wilson, J. L.; Fayad Kobeissi, S.; Oudir, S.; Haas, B.; Michel, B. W.; DuboisRande, J. L.; Ollivier, A.; Martens, T.; Rivard, M.; Motterlini, R.; and Foresti, R. Design and synthesis of novel hybrid molecules that activate the transcription factor Nrf2 and simultaneously release carbon monoxide. Chemistry 2014, 20, 14698-14704.

(7) Rodkey, F. L.; Hill, T. A.; Pitts, L. L.; and Robertson, R. F. Spectrophotometric measurement of carboxyhemoglobin and methemoglobin in blood. Clin. Chem. 1979, 25, 1388-1393. 